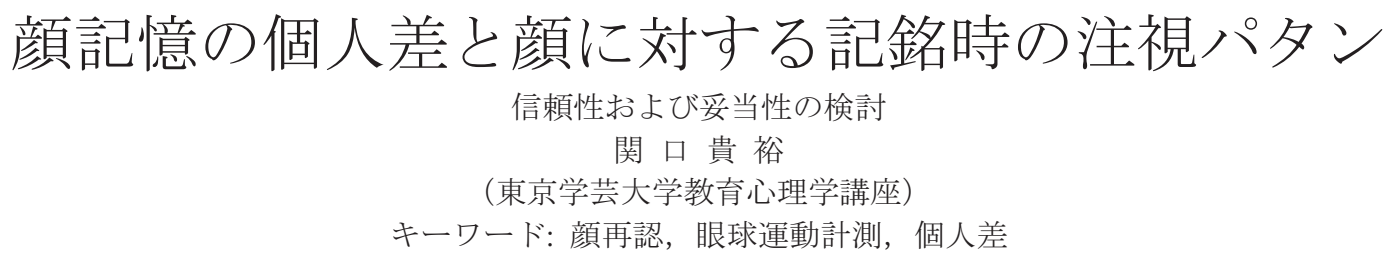

Individual difference in face memory and eye fixation patterns during face learning: Examination of reliability and validity Takahiro SEKIGUCHI

(Department of Educational Psychology, Tokyo Gakugei University)

Key words: Face recognition, Eye movement analysis, Individual difference

顔記憶の個人差に影響する要因として，これまでに視覚記 憶能力や認知スタイル，記銘方略などが指摘されてきた。一 方で，顔の記銘時にそれを構成するどの特徵に注目するか, すなわち顔に対する注視パタンと顔記憶の個人差との関係に ついて検討した研究は少ない。先行研究において Sekiguchi （2008）は，映像中の顔を記銘する際の注視パタンを眼球運動 測定装置により調べ, 10 分後に行った再認課題の成績とそれ との関係を検討した。その結果，再認課題の成績が高い参加 者は，低い参加者に比へ，目に対する注視回数が多いことが 見いだされた。この結果は, 顔記憶能力の個人差に, 目に対 する注視の程度が関与することを示唆している。

しかしながら先行研究の結果は, 顔記憶能力の高い参加者 が，記銘時に目をよく注視していたのではなく，“たまたま” 記銘時に目をよく見ていた参加者が，その結果として，後の 再認課題で高い成績を示したのだと解釈することも可能であ る。すなわち，先行研究における記銘時の注視パタンは，そ れぞれの参加者に固有な顔の見方を反映したものではなく, また再認課題の成績の違いも, 参加者の顔記憶能力とは異な る要因の影響によるものであった可能性が考えられる。そこ で本研究では, 先行研究で記録された顔記銘時の注視パタン が各参加者固有のものであったか否かを明らかにするために， 先行研究に参加した参加者に再度, 同じ課題を実施し, その 注視パタンが再現されるかを検討した（注視パタンの信頼性 の検討)。また, 先行研究における再認課題の成績が, 本当に 参加者の顔記憶能力を反映したものであったか否かを確認す るために, 先行研究の参加者に対し別種の顔記憶テストを実 施し，その成績が再認課題の成績と相関を示すか否か，すな わち先行研究における再認課題の妥当性を検討した。

\section{方 法}

実験参加者：先行研究（Sekiguchi，2008）に参加した 41 名のうち，参加に同意した 29 名（女性 24 名，男性 5 名）。

眼球運動計測: 先行研究における記銘段階の刺激を呈示し, それに対する注視パタンを眼球運動計測装置（EMR-AT VOXER, ナック社）により記録した。刺激は, 協力者に未知 の男女が登場する映像 20 名分であった。映像は 20 秒の長さ で，登場人物が「夏休みに遊びにいく場所」について述べて いる様子をバストショットで撮影したものであった。映像は 音声と共に呈示した。参加者は, 液晶ディスプレイに提示さ れる映像を見て，それぞれにつき登場人物の性格印象を 5 段 階尺度により評価した。先行研究では，顔の記銘を偶発記憶 課題としたため, 本研究では参加者に「顔を覚えることは意 識しないでよい」と教示した。

顔記憶テスト：Duchaine \& Nakayama (2006)の Cambridge Face Memory Test (CFMT) と同様のテストを, 日本人男性の顔 写真を素材に作成した。顔写真には, 財団法人ソフトピアジ ヤパンの所有する顔画像データベースの写真を加工したもの
を使用した。顔記憶テストは，6人の男性の顔を覚えた後， それらに対する 3 つの選択肢からの再認を繰り返すものであ った。顔画像は, 髪の毛および首以下を削除した白黒画像で あり, 左 $30^{\circ}$, 正面, 右 $30^{\circ}$ の 3 つのアングルの写真を学習 用刺激に使用した。テストは, 学習時に使用した写真をター ゲットとしたもの 18 問, 学習時の写真とは異なるアングルの 写真をターゲットとしたもの 30 問, さらにそれらにノイズを 加えたもの 24 問の計 72 問からなっていた。

\section{結 果}

顔に対する注視パタン: 刺激映像における目, 鼻, 口, 髪, 額，煩/耳，あご，首/体，背景の 9 つの領域に対する注視回 数および合計注視時間の平均值を参加者ごとに算出した。注 視は, このうち目, 鼻, 口に集中していた。表は, 目, 鼻, 口の各領域に対する注視回数および合計注視時間について, 本研究のそれと先行研究のそれとの相関係数を示している。 いずれの領域においても中程度に強い相関が得られており, 先行研究における参加者の注視パタンが再現されたと言える。

顔記憶テスト：顔記憶テストの平均正答率は $0.87 （ \mathrm{SD}=$ 0.09）であった。顔記憶テストの值は, 先行研究における再 認記憶課題の成績と中程度に相関していた $(r=0.57, p<.01)$ 。

\section{考 察}

顔に対する注視パタンが，先行研究のそれを再現していた ことから，先行研究における目に対する注視回数の違いは， それぞれの参加者に固有の注視パタンを反映した，信頼性の 高い結果であると言える。また, 先行研究における再認課題 の成績が，本研究における CFMT を元にした顔記憶テストと 中程度に相関したことから, 先行研究の課題が個人の顔記憶 能力を測定するものとして妥当であったことが示された。こ れらの結果から, 顔記憶能力の個人差に目に対する注視の程 度が関与しており, 顔記憶能力の高い者は, 低い者に比べ目 をより多く見ていると明らかにいうことができる。

表. 本研究における目, 鼻, 口へ注視回数, 合計注視時間と 先行研究のそれとの相関係数

\begin{tabular}{|c|c|c|c|c|}
\hline \multirow[b]{2}{*}{ 領域 } & \multicolumn{2}{|c|}{ 注視回数 (回) } & \multicolumn{2}{|c|}{ 合計注視時間 (秒) } \\
\hline & 平均 & $r$ & 平均 & $r$ \\
\hline 目 & 22.4 & .86 & 9.2 & .62 \\
\hline 鼻 & 8.7 & .60 & 3.5 & .65 \\
\hline 口 & 4.0 & .72 & 2.1 & .73 \\
\hline
\end{tabular}

\section{引用文献}

Duchaine, B. \& Nakayama, K. 2006, Neuropsychologia, 44, 576-585.

Sekiguchi, T. 2008, International Journal of Psychology,43, 3/4, 159 (XXIX International Congress of Psychology). 